\title{
Acrylamide in Robusta Coffee on Blood Pressure, Urine Production and Renal Histopathological Change in White Male Rats
}

\author{
Dian Yuliartha Lestari ${ }^{1}$, Isbandiyah Isbandiyah ${ }^{2}$, Fathiyah Savithri ${ }^{3}$, Alfaries Radea \\ Marcianto $^{4}$, Rayyan ${ }^{\mathrm{d}}$ \\ ${ }^{1}$ Department of Pathological Anatomy, Medical Faculty, Muhammadiyah Malang University \\ ${ }^{2}$ Department of Internal Medicine, Medical Faculty, Muhammadiyah Malang University \\ ${ }^{3}$ Department of Farmacology, Medical Faculty, Muhammadiyah Malang University \\ ${ }^{4}$ Medical Student, Muhammadiyah Malang University \\ *Corresponding author: dianyuliarthalestari@gmail.com
}

\begin{abstract}
Background: Coffee is one of the popular drinks whole the world. Coffee's contents are grouped into antioxidant (caffeine) and carcinogenic (acrylamide) agents. The mechanisms both of antioxidant and carcinogenic are contradicted in resulting the depiction of blood pressure, urine production and renal histopathology either protecting or damaging. Objective: To know the steeping effect of Robusta coffee (Coffea canephora var. Robusta) towards blood pressure, urine production and renal histopathology change on white male rats. Method: True Experimental, Post Test Only Control Group Design. Steeping Coffee with certain doses 0,36ml/day; 0,72ml/day; 1,44ml/day and 2,16ml/day were given orally for 28 days. The data analyzed by One Way ANOVA, Tukey, correlation, and regression. Result: The Steeping of Robusta coffee was able to causing an alterations of renal histopathology which characterized by tubular tyroidisasi $(p=0,002)$ with optimal doses was $1,14 \mathrm{ml}$. The correlation values $(0,774)$ showing strong correlation, whereas regression test influenced in the amount of 57,6\%. Steeping coffee could increase blood pressure and urine output significantly $(p=0,000)$ with optimal dose was 2,16ml/day. Each correlation value was 0819 and 0859 that showed a significant correlation, each regression test showed the influence of 67\% and 92.1\%. Conclusion: The Steeping of Robusta coffee increased the alterations of renal histopathology were characterized by tubular tyroidisasi, could increase blood preesure and urine output in white male rats.
\end{abstract}

Keywords:Acrylamide, Robusta Coffee, Urine Production, Blood Pressure, Renal Histopthological

\section{INTRODUCTION}

Coffee is one of the most popular beverages in the world. Many things that make people fall in love with this drink, in addition to its distinctive aroma, coffee also has a sharp and unique taste (Adrogue 2007). Statistics said that the largest type of coffee production is robusta type that reaches more than 471 thousand tons (80\%) (AEKI 2012). Robusta coffee has two main antioxidant content of caffeine acid and also chlorogenic acid with a high enough level. Chlorogenic acid is a polyphenol compound that acts as a major antioxidant along with caffeine acid (Angelia 2006). Chlorogenic acid can inhibit and kill cancer cells by inducing endogenous antioxidants that will bind a number of free radicals in the body so that it is detoxification (Anh Le 2010).

Compounds other than antioxidants began to appear after experiencing penyawraian namely acrylamide. These compounds are carcinogenic and genotoxic in animals. The 
Food and Drug Administration (FDA) has classified acrylamide as a compound that may cause cancer or potentially carcinogenic in humans (group 2A). Based on animal studies try, acrylamide is known to potentially cause organ damage to tumors (Baylin et al. 2006).

The kidneys are the second organ after the liver is most often subjected to chemical damage. One of the most common parts of kidney damage due to chemicals is the renal tubular epithelial cells. Kidney damage varies from mild to severe form of cancer (Bhara 2009).

Coffee can also affect blood pressure due to the presence of caffeine contained in it. Caffeine is thought to have both hypertensive and hypotensive effects, its mechanism of action being as a competitive antagonist to adenosine receptors. This affects the vasoconstriction of blood vessels caused by blockade of adenosine receptor (A) and cAMP accumulation leading to increased peripheral resistance and caffeine may also induce diuretics that are indirectly hypotensive as caffeine increases glomerular filtration and decreases reabsorption sodium in the renal tubules (Corti et al 2007).

Therefore, this study aims to find the effect of acrylamide on robusta coffee on blood pressure, urine production volume and histopathology changes in the kidneys.

\section{METHOD}

This research is true experimental using Post Test Only Control Group Design. This study using rats (Rattus novergicus Wistar strain) healthy male with a lifespan of 10-12 weeks and weigh 180-250 grams counted 25 animals were divided into five groups and each group a total of 5 rats. Group 1 (negative control) are a group of rats fed BR-1 and was not given any treatment. Group 2, 3, 4 and 5 are a group of rats given steeping robusta coffee (Coffea canephora var.Robusta) with each dose $(0.36 \mathrm{ml}, 0.72 \mathrm{ml}, 1.44 \mathrm{ml}, 2.16 \mathrm{ml})$ for 28 days. Prior to the treatment, the mice conducted the process of adaptation. To assess the blood pressure of each samples was done by using tail cuff and blood pressure analysis. To measure urine production each sample is accommodated using a centrifuge tube. Blood pressure measurements and urine production were performed on day 29. After treatment, the mice were killed to see if they were getting tiroidization on the renal tubules. Observations were made in 5 visual field with 400x magnification.

\section{RESULTS AND DISCUSSION}

\section{Blood Pressure}

From Figure 1, it can be seen that in normal mouse treatment $(\mathrm{K})$ the average value of blood pressure $(\mathrm{mmHg})$ is $124.6 \mathrm{mmHg}$. At treatment $(\mathrm{P})$ the dose of robusta coffee (Coffea canephora var. Robusta) subcronically indicates an increase in blood pressure $(\mathrm{mmHg})$. Treatment P1 has an average increase in blood pressure of $144.2 \mathrm{mmHg}, \mathrm{P} 2$ treatment of $147.6 \mathrm{mmHg}, \mathrm{P} 3$ treatment of $177.4 \mathrm{mmHg}$, while the treatment $\mathrm{P} 4$ has the highest average of $179.2 \mathrm{mmHg}$. 


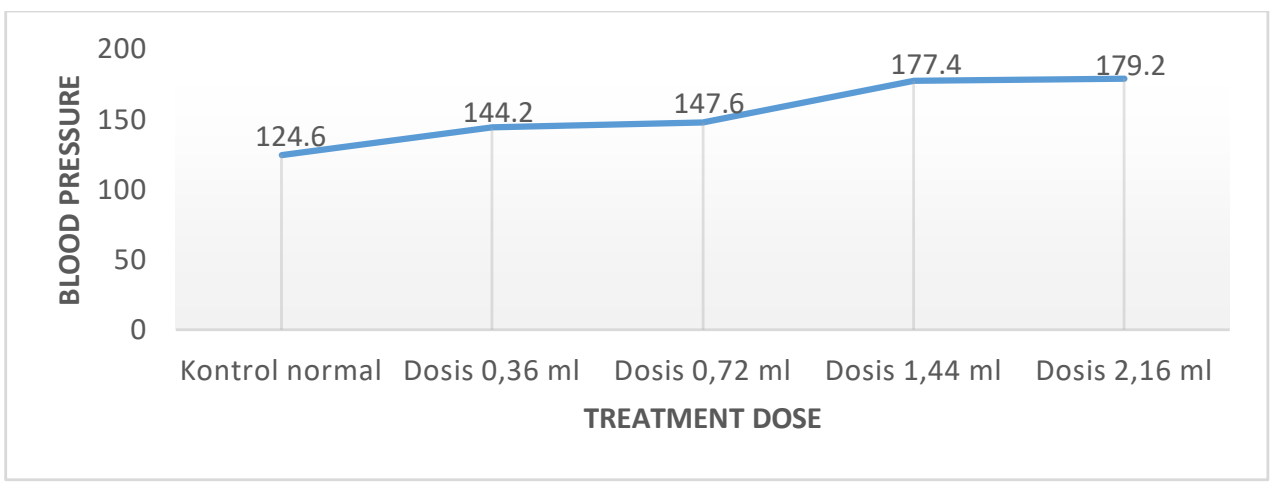

Figure 1. Graph of Average Blood Pressure (mmHg)

\section{Urine Production}

From Figure 2, it can be seen that in normal rat treatment $(\mathrm{K})$ the average value of urine production $(\mathrm{ml})$ is $1.9 \mathrm{ml}$. At the treatment $(\mathrm{P})$ the subsequent dose of robusta coffee (Coffea canephora var. Robusta) indicates an increase in urine production. Treatment P1 has an average increase in urine production of $7.8 \mathrm{ml}, \mathrm{P} 2$ treatment of $8.9 \mathrm{ml}, \mathrm{P} 3$ treatment of $12.5 \mathrm{ml}$, while the treatment $\mathrm{P} 4$ has the highest average of $15.9 \mathrm{ml}$.

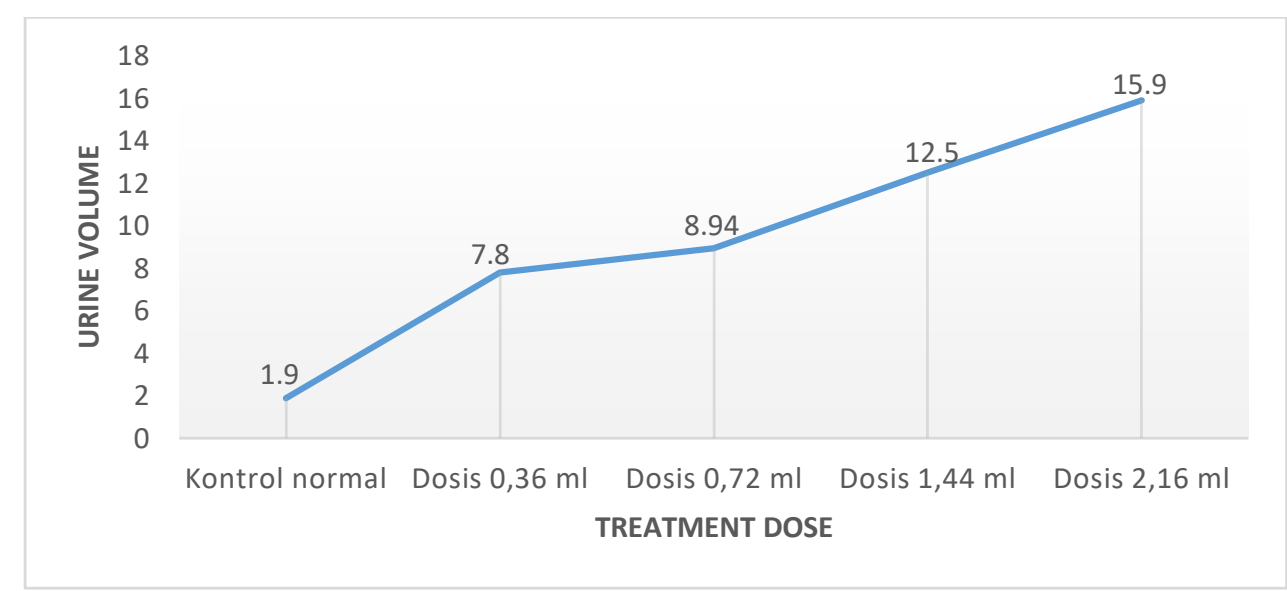

Figure 2. Graph of Average Urine Production (ml)

\section{Renal Histopathology}

Renal histopathology observation was performed with a 400x light magnification microscope, which was observed for the presence or absence of renal tubular thyroidization. Renal tubular thyroidization is characterized by the presence of hyaline cast or eosinophilic amorphous material present in the distal tubule. This suggests that there is an ongoing process of acute tubular necrosis in the kidneys. The tubules undergoing tirodization can be seen in Fig. 3, while the average number of thyloidizations per 10 field of view is presented in Fig.4
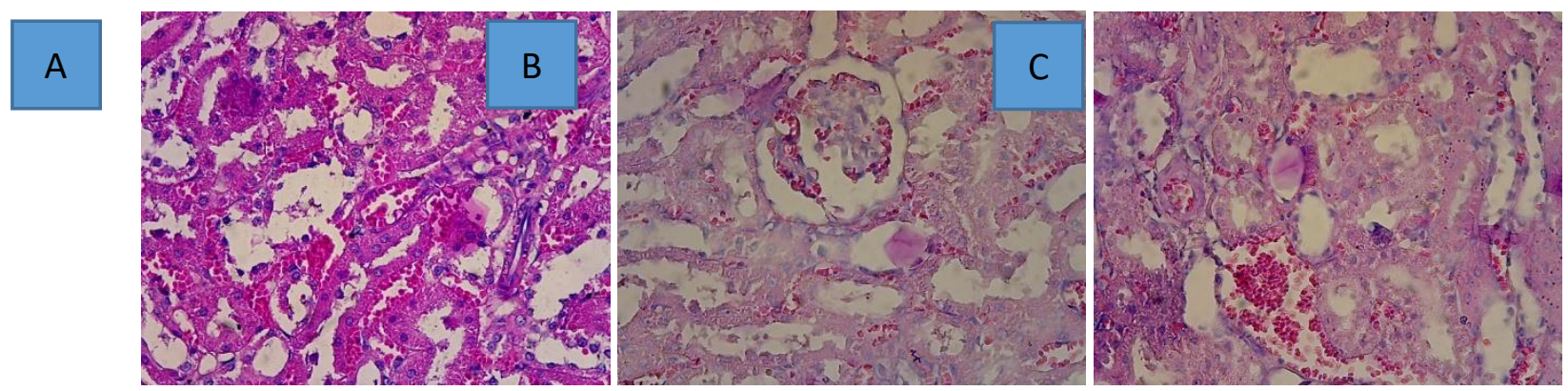

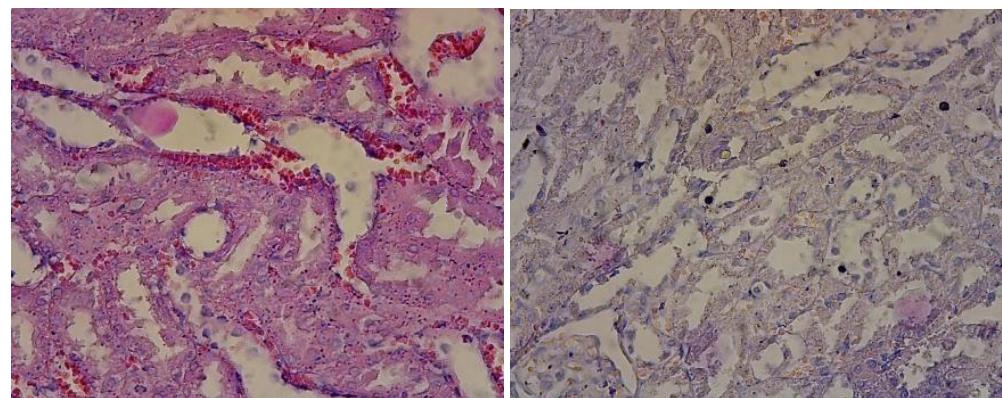

Figure 3. Microscopic images of kidney with $400 x$ magnification. $A=$ negative control group $\mathrm{B}=$ treatment group 1. $\mathrm{C}=$ treatment group 2. $\mathrm{D}=$ treatment group 3. $\mathrm{E}=$ treatment group 4. Black arrows showed renal tubular thyroidization.

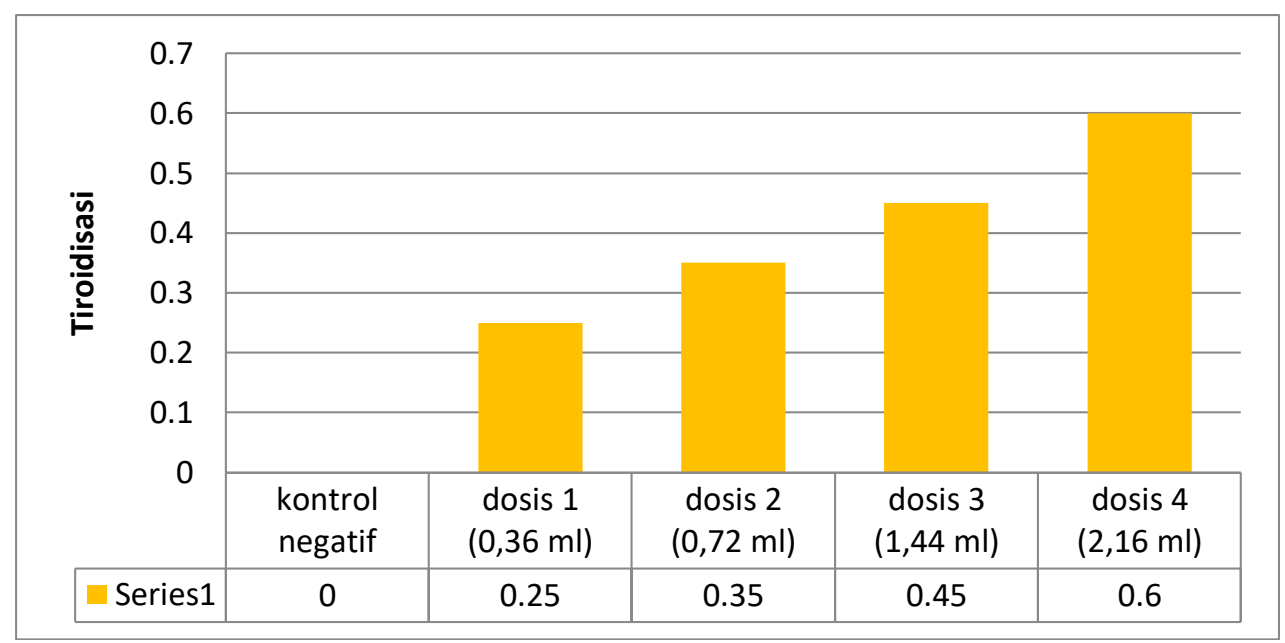

Figure 4. Graph of Average of Tubular Thyroidisation

\section{Data Analysis}

Based on the data obtained, the analysis using ANNOVA test, Tukey test and regression correlation. The results can be seen in table 1 .

Table 1. Statistical Analysis with Annova, Tukey and Pearson's correlation

\begin{tabular}{lccc}
\hline Analisis Statistik & Blood Pressure & Urine Production & Tubulus Thyroidisation \\
\hline Annova (p) & 0,000 & 0,000 & 0,002 \\
\hline Tukey (p) & & & \\
$-\quad$ K- ; P1 & 0,210 & 0,000 & 0,255 \\
$-\quad$ K- ; P2 & 0,105 & 0,000 & 0,060 \\
$-\quad$ K- ; P3 & 0,000 & 0,000 & 0,012 \\
$-\quad$ K- ; P4 & 0,000 & 0,000 & 0,001 \\
\hline Pearson (r) & 0,819 & 0,959 & 0,774 \\
\hline
\end{tabular}

Can be seen in table 1, the three variables (blood pressure, urine production, and tubular thyroidisation) have significant results $(\mathrm{p}<0.05)$, which means that coffee robusta affects the above three variables. For the treatment dose, which had a significant effect on the control group was P4 group (dose $2.16 \mathrm{ml} / 200 \mathrm{grBB}$ ). For the relationship between Robusta coffee deliveries with the three variables have a strong relationship seen from the correlation of pearson approaching the value of 1 . 
This study has proven that substituting Robusta coffee (Coffea canephora var. Robusta) can increase blood pressure and urine production. The treated mice group had blood pressure and urine production was higher when compared with normal controls. Increased blood pressure and urine production are thought to be caused by a mechanism of caffeine found in robusta coffee (Chobanian 2003).

Caffeine is thought to have a mechanism that can affect blood pressure. Caffeine is a competitive antagonist to adenosine receptors, resulting in decreased adenosine activity. Adenosine causes the constriction of the afferent glomerular arteriole, so the inhibition of the adenosine receptor will cause the vasodilation of the arteriole. This widening of blood vessels causes an increase in Renal Blood Flow (RBF) and Glomerulus Filtration Rate (GFR) increases, this is not matched by the maximum reabsorption of $\mathrm{H} 2 \mathrm{O}$ and $\mathrm{Na}+$ into the blood vessels through the tubules resulting in an increase in urinary volume (diuresis) (Echeverri 2010).

In other mechanisms caffeine can increase blood pressure by inhibiting phosphodiesterase (PDE) resulting in cAMP accumulation, the accumulated cAMP increase as a precursor of renin causing vosoconstriction in peripheral blood vessels which may cause peripheral resistance to increase resulting in increased blood pressure (Farah 2012).

In addition, caffeine may inhibit the action of adenosine (A) acting on peripheral blood vessels that cause peripheral and cardiac vasoconstriction resulting in positive positive and chronotropic inotropic effects that cause increased heart contraction, the end result of adenosine receptor (A) constraints on peripheral blood vessels and heart is an increase in blood pressure (Garcia et al. 2008).

In this study was done for 28 days and found mice had hypertension. This increase in blood pressure is thought to be caused by the effects of caffeine already affecting the RAA system (Renin Angiotensin Aldosterone) which has a long-lasting effect on the increase in blood pressure. The results of this increase in blood pressure in accordance with previous research by Noordzij bahwasannya there is an increase in blood pressure in people who consume coffee routine 9 days (Lang), 12 days (Arends), 14 days (Hamer), and Corti research which states the increase in blood pressure after drinking coffee in normal people for 60 minutes.

At the P1 treatment dose, there was no hypertension result in white rat of male wistar strain (Rattus novergicus Strain wistar) but did not rule out with longer induction can cause hypertension as obtained in P2, P3, and P4 treatment dosage in addition to elevated blood pressure is thought to be caused by stimulation of renin by caffeine while in this study did not examine the increase in renin levels so it needs to did further research. In this study the influence of steeping coffee robusta (Coffea canephora var Robusta) can increase blood pressure and urine production respectively with percentage of $67 \%$ and $92.1 \%$ while the rest of $33 \%$ and $7.9 \%$ influenced by other factors outside this study such as stress factors that can increase the hormone cortisol which can then stimulate the formation of renin and disease in mice.

This study also proved that there were differences in the picture of thyroidization in male white rats (Rattus novergicus) Wistar strains between the negative control group and the treatment group. In the male wistar strain mice group with dose of robusta coffee of $2,16 \mathrm{ml} / 200 \mathrm{kgBW}$ had more result of renal tubule epithelial cell thyroidization compared with other dose treatment group.

This mechanism of thyroidization results from the hypersensitivity reaction of renal tubular cells that stimulate the release of proinflammatory cytokines such as macrophages and tubular epithelial tubular lymphocytes, vascular endothelial cells, and inflamed 
intertitial cells. Furthermore, some studies suggest that there is a role of TGF- $\beta$ in causing thyroidization produced directly by components contained in collagen and non-collagen substances accumulated in the basement membrane and indirectly by collagenase and metalloproteinase enzymes that inhibit matrix degradation. The activation of nuclear transcription factors such as NFKB and the release of proinflammatory factors is also a cause of renal tubular damage characterized by thyroidisation (Guessous et al. 2015).

Statistic with Pearson correlation test obtained positive value $(0,774)$ in correlation coefficient indicate that doses of steaming robusta coffee and renal histopathology change seen from picture of renal tubular epithelial cell thyroid that is proportional. That is, the greater the dose of steeping robusta coffee is given, the greater the thyroidisation of renal tubular epithelial cells, the value proves that the greater the dose of steeping robusta coffee is given the higher the acrylamide compounds that are thought to damage the kidney organs.

The result of regression test showed that the effect of robusta coffee dosage on histopathology change of prostate was $57,6 \%$, meaning that the histopathology of kidney is characterized by thyroiditis of renal tubular epithelial cells influenced by dosage of robusta coffee with $57,6 \%$ and the rest of $42.4 \%$ influenced by other factors outside the research of renal disease suffered by previous rats such as immunological disease and / or metabolic disorders, viral infections during experiments by cytomegalovirus and / or viral hepatitis, and also due to stress experienced by rats during experiments that trigger the hormone cortisol is secreted so that renin is activated so that blood pressure increases for a long time causing kidney damage (Guessous et al. 2015).

\section{CONCLUSION}

The Steeping of Robusta coffee increased the alterations of renal histopathology were characterized by tubular tyroidisasi, could increase blood preesure and urine output in white male rats.

\section{REFERENCE}

Adrogue HJ, Madias NE. Sodium and Potassium in the Pathogenesis of Hypertension. N Engl J Med 2007; 356:1966-1978

AEKI. 2012. Area and Production of Coffee in Indonesia. Retrieved 22 May 2015 from: http://www.aeki-aice.org/page/areal-and-production/id

Angelia Bistani, Dina. 2006. Efek Diuretik Kopi Susu Pada Tikus Putih (Rattus novergicus) Dengan Variasi Jenis Susu. Surakarta : Skripsi FMIPA UNS. 4-8, 1517.

Anh Le, 2010, My Organic Chemistry:Name and Structure of Caffeine. diakses pada tanggal 20 September 2014, tersedia dari: https://myorganic chemistry.wikispaces.com/Caffeine

Baylin A, Hernandez-Diaz S, Kabagambe EK, et al. 2006. Transient Exposure to Coffee as a Trigger of a First Nonfatal Myocardial Infarction. Epidemiology 2006;17:506511.

Bhara, M. 2009. The Influence of Graded Coffee Dosage Per Oral 30 Days To The Histopathology Of The Wistar Mouse Histopathology. Semarang: FK UNS Thesis. p.29.

Corti, Roberto, Binggeli C, Sudano I et al.2007. Coffee Acutely Increases Sympathetic Nerve Activity and Blood Pressure Independently of Caffeine Content Role of 
Habitual Versus Nonhabitual Drinking. American Heart Association. Circulation. 2007;106:2935-2940.

Chobanian, Aram V.. 2003. JNC 7 Express. U.S. Department of Health and Human Services. NIH Publication No. 03-5233.

Echeverri, Dario. 2010. Caffeine's VascularMechanisms of Action . International Journal of Vascular Medicine. Article ID 834060. doi:10.1155/2010/834060. p.5-7.

Farah, Adriana. 2012. Coffee: Emerging Health Effects and Disease Prevention ED. I, IFTPressBook. 25-26, 28-38, 41-43.

Garcia, Lopez, E. van Dam, Rodriguez-Artalejo F., et al. 2008. The relationship of coffee consumption with mortality. Annals Internal Medicine, 148. 904-914.

Guessous, Idris, Menno Pruijm, Belén Ponte et al. .2015. Associations of Ambulatory Blood pressure With Urinary Caffeine and Caffeine Metabolite Excretions. Hypertension. 2015;65:691-696

Humayun, Anjum. 2009. Relation of Hypertension With Body Mass Index and Age in Male and Female Population of Peshawar, Pakistan. J Ayub Med Coll Abbottabad 2009 (21); $63-65$. 